\title{
Pulmonary infection in two sympatric lizards, Mabuya arajara (Scincidae) and Anolis brasiliensis (Polychrotidae) from a cloud forest in Chapada do Araripe, Ceará, Northeastern Brazil
}

\author{
Ribeiro, SC. ${ }^{a, e *}$, Ferreira, FS. ${ }^{a}$, Brito, SV. ${ }^{a}$, Teles, DA. ${ }^{b}$, Ávila, $R W^{b}$, \\ Almeida, WO. ${ }^{c}$, Anjos, LA. ${ }^{d}$ and Guarnieri, $M C^{e}$

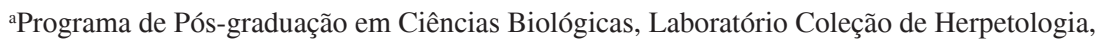 \\ Universidade Federal da Paraíba - UFPB, Cidade Universitária, Campus I, CEP 58059-900, João Pessoa, PB, Brazil \\ ${ }^{\mathrm{b}}$ Departamento de Ciências Biológicas, Universidade Regional do Cariri - URCA, \\ Rua Cel. Antônio Luiz, 1161, Campus do Pimenta, CEP 63105-000, Crato, CE, Brazil \\ 'Departamento de Química Biológica, Universidade Regional do Cariri - URCA, \\ Rua Cel. Antônio Luiz, 1161, Campus do Pimenta, CEP 63105-000, Crato, CE, Brazil \\ ${ }^{\mathrm{d}}$ Laboratório de Parasitologia e Zoologia, Departamento de Biologia e Zootecnia, \\ Universidade Estadual Paulista - UNESP, Passeio Monção, 226, CEP 15385-000, Ilha Solteira, SP, Brazil

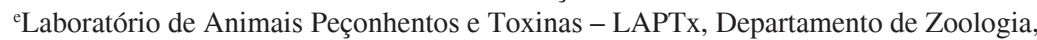 \\ Universidade Federal do Pernambuco - UFPE, Av. Prof. Moraes Rego, 1235, CEP 50670-420, Recife, PE, Brazil \\ *e-mail: ribeiroherpeto@gmail.com
}

Received September 30, 2011 - Accepted February 23, 2012 - Distributed November 30, 2012

\begin{abstract}
The parameters of infection by lung parasites from two sympatric lizards, Mabuya arajara and Anolis brasiliensis, from the Atlantic Rainforest of the lower slope of Chapada do Araripe in Northeastern Brazil were analyzed between September, 2009 and July, 2010. A total of 202 lizards were collected. 125 specimens were from Mabuya arajara and 77 from Anolis brasiliensis. M. arajara was infected by the pentastomid Raillietiella mottae while A. brasiliensis was infected by the nematode Rhabdias sp., with an overall prevalence of $1.6 \%$ and $28.6 \%$, respectively. The mean intensity of infection by Rhabdias sp. was $3.63 \pm 2.58$ (range 1-15). The body size and sex of lizards did not influence the intensity of infection by Rhabdias sp. The overall prevalence was also not different between males and females hosts in A. brasiliensis. Both Anolis brasiliensis and Mabuya arajara represent a new host to Rhabdias sp. and Raillietiella mottae, respectively.
\end{abstract}

Keywords: lizard, pulmonary infection, pentastomida, nematoda.

\section{Infecção pulmonar em dois lagartos simpátricos, Mabuya arajara (Scincidae) e Anolis brasiliensis na mata-úmida da Chapada do Araripe, Ceará, Nordeste do Brasil}

\section{Resumo}

Os parâmetros de infecção por parasitas pulmonares em dois lagartos simpátricos, Mabuya arajara e Anolis brasiliensis, da floresta úmida da encosta da Chapada do Araripe, Nordeste do Brasil, foram analisados entre setembro de 2009 e julho de 2010. Um total de 202 lagartos foi coletado, sendo 125 espécimes de Mabuya arajara e 77 de Anolis brasiliensis. M. arajara estava infectado pelo pentastomídeo Raillietiella mottae, enquanto A. brasiliensis apresentava infecção pelo nematódeo Rhabdias sp., com prevalência total de 1,6\% e 28,6\%, respectivamente. A intensidade média de infecção por Rhabdias sp. foi 3,63 \pm 2,58 (amplitude 1-15). O tamanho e o gênero dos lagartos não influenciaram a intensidade de infecção por Rhabdias sp. A prevalência também não apresentou diferença entre machos e fêmeas em A.brasiliensis. Ambos, Anolis brasiliensis e Mabuya arajara, representam novos hospedeiros para Rhabdias sp. e Raillietiella mottae, respectivamente.

Palavras-chave: lagarto, infecção pulmonar, pentastomida, nematoda. 


\section{Introduction}

Over the last decade, more research has been carried out concerning lizard parasites from South American regions (Ávila and Silva, 2010) and there is a growing body of research of ecological information about lung parasites (Vrcibradic et al., 2002a, b; Dias et al., 2005; Goldberg et al., 2006a, b; Anjos et al., 2007; Almeida et al., 2008a, 2009a) including pentastomids (Anjos et al., 2007, 2008; Almeida et al., 2008a, b, c, 2009a; Bursey et al., 2010).

Mabuya arajara Rebouças-Spieker, 1981 (Scincidae) can be found in mesic environments of high-altitude areas (called "Brejos-de-Altitude") from the state of Ceará, Northeastern Brazil (Roberto and Loebmann, 2010), including the Chapada do Araripe located in the south of the state.

Anolis brasiliensis Vanzolini and Williams, 1970 (Polychrotidae) can be found in open formations of the Amazon region (Ávila-Pires, 1995) and Cerrado (Mesquita et al., 2008), with an isolated population in Chapada do Araripe (Willians and Vanzolini, 1980; Ribeiro et al., 2008).

Despite the numerous studies on lizard parasites in Brazil (Rocha, 1995; Ribas et al., 1998; Vrcibradic et al., 1999; Vicente et al., 2000; Vrcibradic et al., 2001; Vicente et al., 2002; Vrcibradic et al., 2002a, b; Rocha and Vrcibradic, 2003; Rocha et al., 2003; Anjos et al., 2005; Bursey et al., 2010), most focus on species of lizards restricted to biomes and ecosystems from the Southeast region. In relation to lung parasites, only two host species were studied in skinks, Mabuya agilis (Raddi, 1823), which was recorded as a host of an unidentified species of the pentastomid Raillietiella sp. (Vrcibradic et al., 2002a, b) and Trachylepis atlantica (Schmidt, 1945), recorded as a host of Raillietiella freitasi (Motta and Gomes, 1968) (Bursey et al., 2010). Polychrotid lizards are commonly recorded as hosts of lung parasites of the genus Rhabdias (Torres-Ortiz, 1980; Bundy et al., 1987; Dobson et al., 1992; Bursey et al., 2003, 2005; Goldberg et al., 2006a, b; Ávila and Silva, 2010), but $A$. brasiliensis was recorded as being infected only by the gastrointestinal nematode Subulura lacertilia Vicente, Van-Sluys, Fontes and Kiefer, 2000 (Ávila and Silva, 2011). In this study, we investigated the species of pulmonary parasites associated with $M$. arajara and A. brasiliensis in Chapada do Araripe, Northeast Brazil for the first time.

\section{Material and Methods}

This study was carried out on the slope of Chapada do Araripe in the tropical subperennial cloud forest (Rainforest). Lizards were sampled in two areas from the municipality of Crato $\left(07^{\circ} 15^{\prime} 19.6^{\prime \prime} \mathrm{S}\right.$ and $39^{\circ} 28^{\prime} 13.9^{\prime \prime} \mathrm{W}$ and $07^{\circ} 16^{\prime}$ $50.7^{\prime \prime} \mathrm{S}$ and $\left.39^{\circ} 26^{\prime} 18.6^{\prime \prime} \mathrm{W}\right)$ and two area of municipality of Barbalha $\left(07^{\circ} 21^{\prime} 49.7^{\prime \prime} \mathrm{S}\right.$ and $39^{\circ} 17^{\prime} 51^{\prime \prime} \mathrm{W}$ and $07^{\circ}$ 19' 58.5' S and $39^{\circ} 24^{\prime} 38.4^{\prime \prime} \mathrm{W}$ ), Northeast Brazil. Lizards were collected by hand or with a shotgun from September, 2009 to July, 2010. The specimens were euthanized with a lethal injection of lidocaine, the snout-vent length (SVL) measured with a digital calliper (accuracy of $0.01 \mathrm{~mm}$ ), fixed in formalin $10 \%$ and preserved in $70 \%$ alcohol. Voucher specimens were deposited in the Laboratório de Zoologia da Universidade Regional do Cariri (LZ-URCA: 599-621; 677-738).

A total of 202 lizards were collected, where 125 specimens were of Mabuya arajara and 77 of Anolis brasiliensis. Among the specimens of M. arajara, 63 were males (SVL $80.3 \pm 10.2$, range $50-103 \mathrm{~mm}$ ), 55 were females (SVL $89.4 \pm 11.9$, range 54-114 mm) and seven were juveniles (SVL $49.7 \pm 5.7$, range $44-59 \mathrm{~mm}$ ). Concerning A. brasiliensis, 49 were males (SVL 57.6 \pm 6.9 , range $35-72 \mathrm{~mm}$ ) and 28 were females (SVL $57.7 \pm 5.9$, range $46-67 \mathrm{~mm}$ ).

The lungs of the lizards were removed and then examined for the presence of parasites using an optical stereomicroscope. The parasites found were removed, counted and preserved in $70 \%$ alcohol to identify later. Pentastomids were cleared in glycerol, mounted on Hoyer medium at semi-permanent slides and examined with a light microscope. Nematodes were cleared in phenol, identified and voucher specimens were deposited in the Laboratório de Zoologia da Universidade Regional do Cariri (LZ-URCA: 1-4).

The prevalence and mean intensity of infection were determined according to Bush et al. (1997). The effect of the host body size (snout-vent length - SVL) on the intensity of the infection was tested by a Pearson correlation. The Z-test was used to evaluate the differences in prevalence and intensity of infection between the sexes. A discrepancy index (D) was calculated as suggested by Poulin (1993). The index has a minimal value of zero $(D=0)$ when all hosts have the same number of parasites. When all parasites are found in a single host, the aggregation is maximal $(\mathrm{D}=1)$. This index was calculated using the Quantitative Parasitology 3.0 software (Rózsa et al., 2000).

The descriptive statistical analysis utilized throughout the text included mean \pm SD (standard deviation). The statistical analyses were performed using the program BioEstat 5.0.

\section{Results}

Analysing the lungs of Mabuya arajara revealed that only two adult females (SVL $92.2 \mathrm{~mm}$ and $101.6 \mathrm{~mm}$ ) were infected by the pentastomid Raillietiella mottae Almeida et al. (2008) (overall prevalence was 1.6\%) and the intensity of infection ranged from one to three.

In Anolis brasiliensis, one unidentified species of the nematode Rhabdias sp. was found in the lungs of 22 lizards (overall prevalence was $28.6 \%$ and mean intensity of infection was $3.63 \pm 2.58$; range $1-15 \mathrm{~mm}$ ): 15 males (prevalence was $30.6 \%$; mean intensity of infection of $3.0 \pm 3.1$; range $1-13 \mathrm{~mm}$ ) and seven females (prevalence of $25 \%$; mean intensity of infection of $5.0 \pm 5$; range $1-15 \mathrm{~mm}$ ). There was no significant difference in the prevalence of Rhabdias sp. between males and females $(\mathrm{Z}=0.22 ; \mathrm{P}=0.82)$, as well as in the intensity of infection between males and females $(Z=0.97 ; P=0.33)$. The discrepancy index (D) of this suprapopulation of Rhabdias sp. was 0.837. Lizard SVL 
had no effect on the intensity of the infection $(R=0.10$; $\mathrm{P}=0.53 ; \mathrm{N}=22$ ).

\section{Discussion}

Mabuya arajara represents a new host for the pentastomid Raillietiella mottae. This parasite has been reported for a several species of lizard hosts, such as Tropidurus hispidus (Spix, 1825), T. semitaeniatus (Spix, 1825), Phyllopezus periosus Rodrigues, 1986, P. pollicaris (Spix, 1825), Micrablepharus maximiliani (Reinhardt and Luetken, 1862) and Hemidactylus mabouia (Moreau of Jonnès, 1818) (Almeida et al., 2009b). At the Chapada do Araripe, $R$. mottae was recorded at hosts from an anthropogenic area (Almeida et al., 2009b) and from an undisturbed area (present study). According to Poulin (2007), the evolution of parasite life-history strategies and the strategies of host exploitation promote a trade-off between a strategy of specialization on host species (generally with high prevalence) or a strategy of parasitized several host species (generally with low prevalence). This species of pentastomid seems to adopt the second strategy as it was recorded from various lizard species from different degrees of environmental conservation.

Indeed, $M$. arajara showed the lower prevalence recorded for raillietiellids in Brazil (prevalence 1.6\%), suggesting that this is not a common host of $R$. mottae (Almeida et al., 2009b).

Nematode Rhabdias sp. are commonly reported in infecting lizards, especially the genus Anolis (Torres-Ortiz, 1980; Bundy et al., 1987; Dobson et al., 1992; Bursey et al., 2003, 2005; Goldberg et al., 2006a, b; Vrcibradic et al., 2007, 2008; Almeida et al., 2009b; Ávila et al., 2011). Here we showed that $A$. brasiliensis is a new host for the genus Rhabdias. An unidentified species of Rhabdias was recorded infecting the tropidurid T. hispidus with low prevalence $(2.5 \%)$ at open areas on the slope of the Chapada do Araripe (Almeida et al., 2009b). The population of $A$. brasiliensis showed a higher prevalence. The environmental conditions play a fundamental role on survivors of free-living and infecting stages of Rhabdias (Anderson, 2000). Thus, the environmental conditions and ecological traits of lizard hosts could determine the infection rates by this pulmonary parasite.

Rhabdias sp. represents the second species of parasite that infects the lizard A. brasiliensis. To date, only the nematode Subulura lacertilia Vicente, Van-Sluys, Fontes and Kiefer, 2000 was known to infect the intestines of this lizard species (Ávila and Silva, 2011). The prevalence (28.57\%) of Rhabdias sp. did not show the status of core species $(<50 \%)$ (Aho, 1990). However, they were similar to those found in Anolis punctatus Daudin, 1802 (38\% N = 8, Goldberg et al., 2006b), Enyalius bilineatus Dumeril and Bibron, 1837 (33.3\% N = 27, Vrcibradic et al., 2007), and E. iheringii Boulenger, $1885(33.3 \% \mathrm{~N}=6$, Vrcibradic et al., 2008), and high in comparison with T. hispidus (2.5\% N = 80, Almeida et al., 2009b), Anolis fuscoauratus D'Orbigny (1.8\% N =69, Goldberg et al., 2006a) and E. perditus Jackson, 1978 (14.3\% N = 14, Vrcibradic et al., 2008).

To some species of lizards, the sex and body size of hosts could influence the rate of infection (Anjos et al., 2005; Sousa et al., 2007; Barreto-Lima et al., 2011), nevertheless this relationship was not found for this lizard host. Features of hosts such as ecological and physiologic characteristics could determine the differences observed in the relationships between body size and intensity of infection (Aho, 1990; Poulin, 2007).

The suprapopulation of Rhabdias sp. showed an aggregated distribution pattern. According to Poulin (1993), the host population with low prevalence rates the aggregation of parasites which tend to be higher, as shown for this population of A. brasiliensis.

Mabuya arajara and A. brasiliensis are sympatric at the area sampled in the Chapada do Araripe. Nevertheless, they do not share the same fauna of pulmonary parasites. It is known that infection by helminths is directly influenced by extrinsic and intrinsic factors such as the way of foraging, the use of the microhabitat (Ribas et al., 1998; Anjos et al., 2005), diet composition (Rocha, 1995), phylogeny of hosts (Poulin and Mouillot, 2003) and environmental components such as the climate (Ribas et al., 1995). Perhaps, ecological (such as the use of the habitat and diet) and phylogenetic differences can act in a way to impede overlapping of the niche (Pianka, 1973) and, thus reflect in the composition of the communities of parasites of these lizards.

The lungs of the lizards infected by both species of parasites did not show clear signs damage of cells or tissues of this organ. Virtually all free living animals are subject to infections/infestations by parasites as these parasite animals could represent $40 \%$ of richness in this community and exceed, in terms of number, all free-living ones (Poulin and Morand, 2004). Therefore, at low prevalence and intensity of infections, healthy hosts should not have symptoms and pathologies caused by presence of parasites (Bush et al., 2001; Poulin, 2007).

Thus, studies of other groups of endoparasites and ectoparasites are crucial to understand the ecological role of the hosts in the differentiation and structuration of the associated parasite communities.

Acknowledgements - This study was supported by research grants from Fundação Cearense de Apoio ao Desenvolvimento Científico e Tecnológico (BPI - FUNCAP), Conselho Nacional de Desenvolvimento Científico e Tecnológico (CNPq), Coordenação de Aperfeiçoamento de Pessoal de Nível Superior (CAPES) e Fundação de Amparo à Pesquisa do Estado de São Paulo (FAPESP 2008/50417-7). A license was provided by IBAMA (IBAMA, process 20388-1 and 23544-1). We would like to thank Elizabeth Martínez-Salazar, Henrique Caldeira Costa, Yury Kuzmin, Jefferson Thiago, Thyago Almeida who helped with sending materials, discussions, suggestions and encouragement. Thanks to Guilherme Sousa for the field assistance. We would like to thank the owners of particular areas where fieldwork was conducted: Raimundo Marques (Nascente, Delvechia grange); Ivan de Araújo B. Filho (São Joaquim Farm, Itapuí-S.A); Rener (Grangeiro club). 


\section{References}

AHO, JM., 1990. Helminthes communities of amphibians and reptiles: comparative approaches to understanding patterns and process. In ESCH, GW., BUSH, AO. and AHO, JM. (Eds.). Parasite communities: patterns and process. London; New York: Chapman \& Hall. p. 157-190.

ALMEIDA, WO, FREIRE, EMX. and LOPES, SG., 2008a. A new species of Pentastomida infecting Tropidurus hispidus (Squamata: Tropiduridae) from caatinga in Northeastern. Revista Brasileira de Biologia = Brazilian Journal of Biology, vol. 68, no. 1, p. 631-637.

ALMEIDA, WO., SANTANA, GG., VIERIA, WLS., WANDERLEY, IC., FREIRE, EMX. and VASCONCELLOS, A., 2008b. Pentastomid, Raillietiella mottae Almeida, Freire \& Lopes, 2008, infecting lizards in an area of caatinga, Northeast, Brazil. Revista Brasileira de Biologia = Brazilian Journal of Biology, vol. 68, no. 2, p. 203-207.

ALMEIDA, WO., SANTANA, GG., VIEIRA, WLS. and WANDERLEY, IC., 2008c. Infection rates of pentastomids on lizards in urban habitats from Brazilian Northeast. Revista Brasileira de Biologia = Brazilian Journal of Biology, vol. 68, no. 4, p. 885-888. PMid:19197509.

ALMEIDA, WO., SANTANA, GG., VIEIRA, WLS., WANDERLEY, IC. and RIBEIRO, SC., 2009a. Rates of pulmonary infection by pentastomids in two lizard species from a restinga habitat in northeastern Brazil. Revista Brasileira de Biologia $=$ Brazilian Journal of Biology, vol. 69, no. 1, p. 631-637.

ALMEIDA, WO., RIBEIRO, SC., SANTANA, GG., VIEIRA, WLS., ANJOS, LA. and SALES, DL., 2009b. Lung infection rates in two sympatric Tropiduridae lizard species by pentastomids and nematodes in northeastern Brazil. Revista Brasileira de Biologia= Brazilian Journal of Biology, vol. 69, no. 3, p. 631-637.

ANDERSON, RC., 2000. Nematode Parasites of Vertebrates. Their Development and Transmission. New York: CABI Publishing. 650 p.

ANJOS, LA., ROCHA, CFD., VRCIBRADIC, D. and VICENTE, JJ., 2005. Helminths of the exotic lizard Hemidactylus mabouia from a rock outcrop area in southeastern Brazil. Journal of Helminthology, vol. 79, no. 4, p. 307-13. PMid:16336713. http:// dx.doi.org/10.1079/JOH2005288

ANJOS, LA., ALMEIDA, WO., VASCONCELLOS, A., FREIRE, EMX. and ROCHA, CFD., 2007. The alien and native pentastomids fauna of an exotic lizard population from Brazilian Northeast. Parasitology Research, vol. 101, no. 3, p. 627-628. PMid:17384963. http://dx.doi.org/10.1007/s00436-007-0526-7

-, 2008. Pentastomids infecting an invader lizard, Hemidactylus mabouia (Gekkonidae) in northeastern Brazil. Revista Brasileira de Biologia = Brazilian Journal of Biology, vol. 68, no. 3, p. 611-615. http://dx.doi.org/10.1590/S1519-69842008000300019

ÁVILA, RW. and SILVA, RJ., 2010. Checklist of helminths from lizards and amphisbaenians (Reptilia, Squamata) of South America. The Journal of Venomous Animals and Toxins including Tropical Diseases, vol. 16, no. 4, p. 543-572. http://dx.doi.org/10.1590/ S1678-91992010000400005

-, 2011. Helminths of Lizards (Reptilia: Squamata) from Mato Grosso State, Brazil. Comparative Parasitology, vol. 78, p. 129-139. http://dx.doi.org/10.1654/4473.1
ÁVILA, RW., CARDOSO, MW., ODA, FH. and SILVA, RJ., 2011. Helminths from lizards of Cerrado of Goiás State, Brazil. Comparative Parasitology, vol. 78, p. 120-128.

ÁVILA-PIRES, TCS., 2005. Lizards of Brazilian Amazonia. Zoologische verhandelingen Leiden, vol. 299, p. 1-706.

BARRETO-LIMA, AF., TOLEDO, GM. and ANJOS, LA., 2012. The nematode community in the Atlantic rainforest lizard Enyalius perditus Jackson, 1978 from southeastern Brazil. Journal of Helminthology, vol. 85, p. 1-6.

BUNDY, DAP., VOGEL, P. and HARRIS, EA., 1987. Helminth parasites of Jamaican Anoles (Reptilia: Iguanidae): on a comparison of the helminth fauna of 6 anoles species. Journal of Helminthology, vol. 61, no. 1, p. 77-83. http://dx.doi.org/10.1017/ S0022149X00009767

BURSEY, CR., GOLDBERG, SR. and PARMELEE, JR., 2005. Gastrointestinal helminths from 13 species of lizards from Reserva Cuzco Amazonico, Peru. Comparative Parasitology, vol. 72, p. 50-68. http://dx.doi.org/10.1654/4132

BURSEY, CR., GOLDBERG, SR. and TELFORD, SR., 2003. Rhabdias anolis $\mathrm{n}$. sp. (Nematoda: Rhabdiasidae) from a lizard, Anolis frenatus (Sauria: Polychrotidae), from Panama. Journal of Parasitology, vol. 89, no. 1, p. 113-117. http://dx.doi. org/10.1645/0022-3395(2003)089[0113:RANSNR]2.0.CO;2

BURSEY, CR., ROCHA, CFD., MENEZES, VA., ARIANI, CV. and VRCIBRADIC, D., 2010. New species of Oochoristica (Cestoda Trachylepis atlantica (Sauria: Scincidae) from Fernando de Noronha Island, Brazil. Zootaxa, vol. 2715, p. 45-54.

BUSH, A., FERNÁNDEZ, J., ESCH, J. and SEED, J., 2001. Parasitism: The diversity and ecology of animal parasites. Cambridge: Cambridge University Press. 566 p.

BUSH, AO., LAFFERTY, KD., LOTZ, JM. and SHOSTAK, AW., 1997. Parasitology meets ecology in its own terms: Margulis et al. revisited. Journal of Parasitology, vol. 83, p. 575-583.

DIAS, EJR., VRCIBRADIC, D. and ROCHA, CFD., 2005. Endoparasites infecting two species of whiptail lizards (Cnemidophorus abaetensis and C. ocellifer; Teiidae) in a restinga habitat of northeastern Brazil. Herpetological Journal, vol. 15 , no. 2 , p. 133-137.

DOBSON, AP., PACALA, SV., ROUGHGARDEN, JD., CARPER, ER. and HARRIS, EA., 1992. The parasites of Anolis lizards in the northern Lesser Antilles I. Patterns of distribution and abundance. Oecologia, vol. 91, no. 1, p. 110-117.

GOLDBERG, SR., BURSEY, CR. and VITT, LJ., $2006 \mathrm{a}$. Helminths of the brown-eared anole, Norops fuscoauratus (Squamata, Polychrotidae) from Brazil and Ecuador, South America. Phyllomedusa, vol. 5, p. 83-86.

-, 2006b. Parasites of two lizard species, Anolis punctatus and Anolis transversalis (Squamata: Polychrotidae) from Brazil and Ecuador. Amphibia-Reptilia, vol. 27, no. 4, p. 575-9. http://dx.doi. org/10.1163/156853806778877068

MESQUITA, DO., SHEPARD, DB., VIEIRA, GHC., CALDWELL, JP. and COLLI, GR., 2008. Ecology of Anolis nitens brasiliensis in Cerrado Woodlands of Cantão. Copeia, vol. 1, p. 144-153.

PIANKA, ER., 1973. The structure of lizard communities. The Annual Review of Ecology, Evolution, and Systematics, vol. 4, p. 53-74. http://dx.doi.org/10.1146/annurev.es.04.110173.000413

POULIN, R., 1993. The disparity between observed and uniform distributions: a new look at parasite aggregation. International Journal 
Parasitology, vol. 23, p. 937-944. http://dx.doi.org/10.1016/00207519(93)90060-C

-, 2007. Evolutionary ecology of parasites. 2nd ed. Princeton: Princeton University Press. 332 p.

POULIN, R. and MORAND, S., 2004. Parasite biodiversity. Washington: Smithsonian Books.

POULIN, R. and MOUILLOT, D., 2003. Parasite specialization from a phylogenetic perspective: a new index of host specificity. Parasitology, vol. 126, p. 473-480. PMid:12793652. http://dx.doi. org/10.1017/S0031182003002993

RIBAS, SC., ROCHA, CFD., TEIXEIRA-FILHO, PF. and VICENTE, JJ., 1995. Helminths (Nematoda) of the lizard Cnemidophorus ocellifer (Sauria: Teiidae): assessing the effect of rainfall, body size and sex in the nematode infection rates. Ciência e Cultura, vol. 47, p. 88-91.

-, 1998. Nematode infection in two sympatric lizards (Tropidurus torquatus and Ameiva ameiva) with different foraging tactics. Amphibia Reptilia, vol. 19, no. 3, p. 323-30. http://dx.doi. org/10.1163/156853898X00232

RIBEIRO, SC., FERREIRA, FS., BRITO, SV., SANTANA, GG., VIEIRA, WLS., ALVES, RRN. and ALMEIDA, WO., 2008. The Squamata fauna of the Chapada do Araripe, northeastern Brazil. Cadernos de Cultura e Ciência, vol. 2, p. 67-76.

ROBERTO, IJ. and LOEBMANN, D., 2010. Geographic distribution and parturition of Mabuya arajara Rebouças-Spieker, 1981 (Squamata, Sauria, Scincidae) from Ceará, northeastern Brazil. Herpetological Bulletin, vol. 113, p. 4-10.

ROCHA, CFD., 1995. Nematode parasites of the Brazilian sand lizard, Liolaemus lutzae. Amphibia Reptilia, vol. 16, p. 412-415. http://dx.doi.org/10.1163/156853895X00505

ROCHA, CFD. and VRCIBRADIC, D., 2003. Nematode assemblages of some insular and continental lizard hosts of the genus Mabuya Fitzinger (Reptilia, Scincidae) along the eastern Brazilian coast. Revista Brasileira de Zoologia, vol. 20, no. 4, p. 755-9. http:// dx.doi.org/10.1590/S0101-81752003000400031

ROCHA, CFD., VRCIBRADIC, D., VICENTE, JJ. and CUNHABARROS, M., 2003. Helminths infecting Mabuya dorsivittata (Lacertilia, Scincidae) from a high-altitude habitat in Itatiaia National Park, Rio de Janeiro State, southeastern Brazil. Brazilian Journal of Biology, vol. 63, no. 1, p. 129-32. http://dx.doi.org/10.1590/ S1519-69842003000100017

RÓZSA, L., REICZIGEL, J. and MAJOROS, G., 2000. Quantifying parasites in samples of hosts. Journal of Parasitology, vol. 86, p. 228-232. PMid:10780537.

SOUSA, BM., LIMA, SS. and OLIVEIRA, A., 2007. Gastrointestinal helminth fauna of Enyalius perditus (Reptilia: Leiosauridae):
Relation to host age and sex. Journal of Parasitology, vol. 93, no. 1, p. 211-3. PMid:17436969. http://dx.doi.org/10.1645/GE-852R1.1

TORRES-ORTIZ, RA., 1980. Otro hospedador final para Rhabdias sp.(Nematoda) e implicaciones evolutivas de las especies del hospedador. Caribbean Journal of Science, vol. 16, no. 1, p. 09-114.

VICENTE, JJ., VRCIBRADIC, D., MUNIZ-PEREIRA, LC. and PINTO, PM., 2000. Skrjabinodon heliocostai sp. n. (Nematoda, Pharyngodonidae) parasitizing Mabuya frenata (Cope) (Lacertilia, Scincidae) in Brazil and the reallocation of Skrjabinodon capacyupanquii (Freitas, Vicente \& Ibanez) in the genus Telandros Wedl. Revista Brasileira de Zoologia, vol. 17, p. 361-367.

VICENTE, JJ., VRCIBRADIC, D., ROCHA, CFD. and PINTO, RM., 2002. Description of Skrjabinodon spinosulus sp. n. (Nematoda, Oxyuroidea, Pharyngodonidae) from the Brazilian lizard Mabuya dorsivittata Cope, 1862 (Scincidae). Revista Brasileira de Zoologia, vol. 19, no. 1, p. 157-62.

VRCIBRADIC, D., ANJOS, LA., VICENTE, JJ. and BURSEY, CR., 2008. Helminth parasites of two sympatric lizards, Enyalius iheringii and E. perditus (Leiosauridae), from an Atlantic Rainforest area of southeastern Brazil. Acta Parasitologica, vol. 53, no. 2, p. 222-5. http://dx.doi.org/10.2478/s11686-008-0027-6

VRCIBRADIC, D., ROCHA, CFD., BURSEY, CD. and VICENTE, JJ., 2002a. Helminths infecting Mabuya agilis (Lacertilia, Scincidae) in a 'restinga' habitat (Grumari) of Rio de Janeiro, Brazil. Amphibia Reptilia, vol. 23, no. 1, p. 109-114.

-, 2002b. Helminth communities of two sympatric skinks (Mabuya agilis and Mabuya macrorhyncha) from two 'restinga' habitats in southeastern Brazil. Journal of Helminthology, vol. 76, no. 4, p. 355-361. PMid:12498642.

VRCIBRADIC, D., ROCHA, CFD., RIBAS, SC. and VICENTE, JJ., 1999. Nematodes infecting the skink Mabuya frenata in Valinhos, São Paulo State, southeastern Brazil. Amphibia Reptilia, vol. 20, p. 333-339. http://dx.doi.org/10.1163/156853899X00367

VRCIBRADIC, D., ROCHA, CFD., VAN SLUYS, M. and BURSEY, CR., 2001. Mabuya macrorhyncha (NCN) Endoparasites. Herpetological Review, vol. 32, p. 256.

VRCIBRADIC, D., VICENTE, JJ. and BURSEY, CR., 2007. Helminths infecting the lizard Enyalius bilineatus (Iguanidae, Leiosaurinae), from an Atlantic Rainforest area in Espirito Santo state, southeastern Brazil. Amphibia Reptilia, vol. 28, p. 166-169. http://dx.doi.org/10.1163/156853807779799009

WILLIANS, EE. and VANZOLINI, PE., 1980. Notes and biogeographic comments on Anoles from Brasil. Papéis Avulsos de Zoologia, vol. 34, no. 6, p. 99-108. 
